\title{
Pancasila and Civic Education Learning as an Adhesive of Multicultural Society
}

\author{
$1^{\text {st }}$ Bambang Sumardjoko \\ Department of Indonesian \\ Language Education, \\ Muhammadiyah University, \\ Surakarta, Indonesia, Yani Street, \\ Po Box 1, Pabelan, Kartasura, \\ Surakarta 57102 \\ bs131@ums.ac.id
}

\author{
$2^{\text {nd }}$ Eko Supriyanto \\ Department of Indonesian \\ Language Education, \\ Muhammadiyah University, \\ Surakarta, Indonesia, Yani Street, \\ Po Box 1, Pabelan, Kartasura, \\ Surakarta 57102 \\ eko.supriyanto@ums.ac.id
}

\author{
$3^{\text {rd }}$ Harun Joko Prayitno \\ Department of Indonesian \\ Language Education, \\ Muhammadiyah University, \\ Surakarta, Indonesia, Yani Street, \\ Po Box 1, Pabelan, Kartasura, \\ Surakarta 57102 \\ harun.pravitno@ums.ac.id
}

\begin{abstract}
The objective of this research was to describe (1) the profile of Pancasila and Civic Education teachers in Surakarta, (2) the teacher's understanding on the essence of Pancasila and Civic Education learning, and (3) the characteristics of Pancasila and Civic Education learning as social adhesive in multicultural society. The research design employed was research and development. The subject of research consisted of Junior High School teachers in Surakarta. Techniques of collecting data used were observation, interview, document analysis, questionnaire and FGD. Data validation was carried out using data or source triangulations. Data analysis was conducted using interactive model of analysis. The results of research were as follows: (1) Generally, Pancasila and Civic Education teachers in Junior High Schools in Surakarta have had Pancasila and Civic Education background and have had long teaching experience. (2) Pancasila and Civic Education teachers have very adequate experience with scientific activity, at local and national levels, so that their understanding on the essence and the objective of Pancasila and Civic Education learning. (3) The development of powerful Pancasila and Civic Education learning is useful as social adhesive for the students in living within multicultural society. For that reason, there should be revitalization on Pancasila and Civic Education learning, particularly related to the integration of social harmony values and learning strategy supporting the mastery of Pancasila and Civic Education competency.
\end{abstract}

Keywords - model; learning; Pancasila and Civic Education; multicultural.

\section{INTRODUCTION}

The plurality of Indonesian community and nation, when treated wisely and prudently is the basic capital of human resource. On the other hand, it can result in social susceptibility. Many riots occurring recently are a tragedy due to plurality not treated wisely thereby resulting in social distance potentially leading to conflict and triggering social disintegration. All of those threaten the nationalism and do not respect society plurality as typical characteristics of Indonesian nation. Therefore, there should be a building attempt to create peaceful culture valuing human rights, and ensuring social bonds. As suggested by Furnivall, South Asian plural society, particularly in Indonesia, will be entrapped into anarchy when they fail to find adequate pluralist federation formula (Azra, 2006).

A strategy taken to anticipate such the failure is to reinforce learning at school. School institution or more broadly, education field contributes more widely to giving solution to a conflict as it can build an awareness of the importance of social harmony systematically. As explained by Sa'dijah, Cholis (2009), school actually provides space to reinforce knowledge base and life experience of students thereby can value diversity and plurality.

Article 3 of Law Number of 2003 states that "national education functions to develop ability and to create the nation's dignified disposition and civilization in the attempt of educating the life of people aiming to develop the students' potency in order to be human beings who are faithful and cautious to the One and Only God, having noble character, healthy, knowledgeable, creative, independent, and becoming democratic and responsible citizens". For that reasons, one of national education executing instruments to achieve the objective of education is Pancasila and Civic Education. Pancasila and Civic Education learning enacted from Elementary School to College level is expected to create the character of citizens who know, realize, and is available to undertake their right and obligation as citizen according to the 1945 Constitution.

As the subject at education unit level, Pancasila and Civic Education has a mission to be value education for young citizens. Pancasila and Civic Education learning is an attempt of maintaining and preserving Pancasila preventively, by attempting to 
improve its definition, understanding, conception, and implementation through education, illumination, national consciousness building, archipelago insight consciousness building, and other preventive measures. In other words, Pancasila and Civic Education is a subject designed to equip students with faith and noble character as directed by Indonesian life ideology, Pancasila. Through learning Pancasila and Civic Education, the students are prepared to participate as effective and responsible citizens. Thus, Pancasila and Civic Education learning is designed as the subject of learning containing cognitive, affective and psychomotor dimensions that are confluent or interpenetrating and integrated into idea, value, concept and moral substance of Pancasila, democratic citizenship, and state defense (Budimansyah, 2008: 24).

The reality shows that Pancasila and Civic Education learning is considered as emphasizing more on political regime's interest with unattractive and formalistic material. Learning process does not encourage the students' critical thinking ability. It is because (1) the material taught tend to be verbalistic over moral values of Pancasila as civic virtue, (2) the learning model tends to be cognitive recitation. As a result, learning process leads to saturation, because the material taught tends to be monotonous, theoretic, and cognitive and even verbalistic (Samsuri, 2010: 130).

Considering description above, Pancasila and Civic Education learning should be developed appropriate to demand and need of nation character development, the learning that can realize the end goal of civic education that is smart and good citizen, the citizens characterized with growth and development of sensitivity, responsiveness, criticizing ability, and social creativity in the context of living within multicultural society orderly, peacefully, and creatively. The students are conditioned to always be critical and to behave creatively as school member, school citizen, society member, citizen, and human being in their smart and good environment. Learning process is organized into learning by doing, social problem solving learning, socio-participatory learning, and learning through social-cultural interaction with the context of society life.

For that reason, a development of Pancasila and Civic Education learning model should be conducted in Junior High Schools based on diversity as the social adhesive in multicultural society. This learning model development is a media of realizing Pancasila and Civic Education Competency involving civic knowledge, civic skills, and or civic dispositions. In addition, the development is intended as the attempt of developing three dimensions of Pancasila and Civic Education: curricular, academic, and socialcultural programs simultaneously. Considering this phenomenon, this research is conducted. Meanwhile, the objective of research and development in detail is to describe: (1) the profile of Pancasila and Civic Education teachers in Surakarta, (2) the teacher's understanding on the essence of Pancasila and Civic
Education learning, and (3) the characteristics of Pancasila and Civic Education learning as social adhesive in multicultural society.

\section{METHOD}

This research and development is productoriented, the process of which is described precisely and thoroughly. The product intended is a description of Pancasila and Civic Education learning in SMP (Junior high school) based on diversity as social adhesives in multicultural society. Research and development (Gall \& Borg, 2003) was selected as it has advantages, particularly viewed from its work procedure, thereby can be used to observe real need and situation of Junior High Schools in Surakarta systematically and cyclically. The research was taken place in Surakarta City. Primary and secondary data was collected from informants, seeing document, place and event (Miles, \& Huberman, 1992) with some techniques such as in-depth interview with Pancasila and Civic Education teachers and officials of Surakarta City's National Education Office. Observation technique was conducted to see Pancasila and Civic Education learning process in the class, content analysis/listening method, and focused group discussion with practitioners. Data validation was conducted using data triangulation and data analysis using interactive model.

\section{RESULTS AND DISCUSSION}

\section{A. Profile of Pancasila and Civic Educationteachers} in Junior High Schools in Surakarta

Considering document in Surakarta Education and Sport Services, it can be found that there are 70 junior high schools in Surakarta: 27 Public, 2 SBI (Internationally Standardized School) and 43 private. The 43 private Junior High Schools consisted of 18 Islam, 9 Christian, 6 Catholic, and 10 general private ones. In undertaking their duty, Pancasila and Civic Education teachers are affiliated with Pancasila and Civic Education subject teacher of Junior High Schools throughout Surakarta City (MGMP PPKN SMP of Surakarta City). This organization holds routine meeting for all members at least four times in one semester. The next activity involving all members are highly dependent on situation developed or urgency. It is because of the preoccupation of members in individual schools. The meeting is usually held in SMP Negeri 2 and SMP Negeri 12 Surakarta, functioning as secretariat.

MGMP PPKN SMP of Surakarta City has an activity agenda, to which all activities conducted in each school year refer. The activity includes MGMP meeting in the beginning of school year to organize learning set for odd semester, reviewing, and evaluating the activities that havebeen conducted during the year. Next activity is to develop module as supporting book, to develop 
mid-semester test and end-semester test items. Then, MGMP conducts meeting in the beginning of even semester to develop learning administration, developing Student Worksheet, mid-semester test and end-semester test items.MGMP PPKn SMP Surakarta is a forum of subject teacher activity in the attempt of to developing its members' personality and professionalism. MGMP evidently serves as coordinator effectively and produces Pancasila and Civic Education learning set as the guidance in Junior High Schools in Surakarta.

Considering the data of teacher becoming the pre-survey research informants consisting of 14 teachers coming from public junior high schools in Surakarta, it can be found some data. Viewed from school level and school group classifications, those 14 teachers can represent Public Junior High Schools existing in Surakarta City (SMPN 1, SMPN 2, SMPN 4, SMPN 10, and SMPN 19). All teachers have bachelor of Pancasila and Civic Education background and tenure of 5-35 years. The long teaching experience represents that Pancasila and Civic Education teachers in Surakarta have been experienced in teaching Pancasila and Civic Education and familiar with learning characteristics of Junior High School students. All informants have scientific activity experience at local or national level.

\section{B. Teachers' understanding on Pancasila and Civic Education}

All respondents agree that Pancasila and Civic Education at schooling level aiming to prepare students to be smart and good citizens. The objective is detailed into some items understandable to teachers: (1) citizens who master knowledge, (2) have skills, (3) develop attitudes and values and utilized to grow the feeling of nationalism and love to homeland. This finding shows that teachers have had good understanding on Pancasila and Civic Education concept and objective.

Then, to this Pancasila and Civic Education learning development, a respondent explain that originally, Pancasila and Civic Education becomes a distinctive subject. All respondents recognize that the development of Pancasila and Civic Education is replete with political development aroma. For example, during 19841990, Pancasila and Civic Education contains so many "Pancasila" contents and during 2012-2018, this subject is inserted with materials important to society life, such aseducationof anti-corruption, noble character, traffic orderliness, citizen right and obligation, and etc.

Reform order generated euphoria in 1998 and symbols of new order were considered as latent hazard that should be buried deeply. Thus, Pancasila became marginalized in dialectics of living within nation. Even in National Education, the existence of Pancasila and Civic Education was eroded. Pancasila Moral Education as a subject was renamed with Civic Education without Pancasila frills. The content of Civic Education derives from Pancasila itself. Civic Education is considered as important to teach as it contains broader citizenship material not only originating directly from Pancasila but also learning Civic Education material for some students just like learning the second-stage Pancasila or is not much different from Pancasila Moral and Nation's History Education.

Pancasila and Civic Education in Indonesia is are multi-dimension in nature, meaning that Pancasila and Civic Education is not only intended to one objective. Winataputra (2001) suggested that there are three dimensions in Pancasila and Civic Education: (1) as curricular program, that Pancasila and Civic Education is designed and taught to students at certain education level, (2) as academic program, a scientific study program conducted by Pancasila and Civic Education academic community using scientific research approach and method to solve conceptual and operation problems in order to result in generalization and theory to construct the body of science. (3) Pancasila and Civic Education as social-cultural program is developed in the context of society life with all members of community being the target. The objective is to build members of society to be good citizens, realizing the importance of social harmony in the society. Teachers' understanding on Pancasila and Civic Education in Indonesia that is multidimensional in nature can be explained as follows. The definition of multi-dimensional content is understood by all teachers $(100 \%)$, that Pancasila and Civic Education contains (1) moral value education, (3) social education, (3) political education, and (4) state defense education. In addition to the answers aforementioned, four teachers add that Pancasila and Civic Education is multidimensional to create a smart and good citizen as well.

Although teachers understand very much the essence of Pancasila and Civic Education, in reality the method used most frequently in the class is lecturing because of so many materials of Pancasila and Civic Education, limited time allocation, and less active participation of students. In responding to the students' less active participation, teachers use a variety of methods such as debriefing, discussion, and assignment. It indicates that teachers' ability and creativity in creating active student-centered learning are inhibited by the number of materials disproportional with time allotment.

Difficulty and constraints the teachers encounter during diversity-based Pancasila and Civic Education learning are varying. Considering the result of interview, the constraints include: (1) 
the poor compatibility between Pancasila and Civic Education material and time allotment in curriculum, (2) teachers are faced with students' low motivation in attending Pancasila and Civic Education lesson in the class, (3) teachers are faced with students' perception that Pancasila and Civic Education is not too important, (4) in inculcating Pancasila and multicultural values, teacher sometimes are faced with the reality of society inconsistent with learning material, (5) teachers sometime find constraints in applying student-centered learning method, model, and strategy, and (6) teachers feel that delivering Pancasila and Civic Education material is actually easy but the important essence of Pancasila and Civic Education with the end goal of knowledge and field implementation has not been achieved maximally yet.

\section{Pancasila Learning as Social Adhesive of Society}

Concept of Pancasila and Civic Education learning in pedagogic review is a scholarship study, curricular program and social-cultural activity that is which are multidimensional in nature. In Indonesia, the direction of Pancasila and Civic Education cannot get out of the foundations of Pancasila ideology, 1945 Constitution, and operational foundation of Law No. 20 about 2003 about National Education System. In addition, it cannot get out of Republic of Indonesia state corridor and Unity in Diversity philosophy as well.

Indonesia has multiethnic, multicultural, and multireligion potential richness, all of which are the potencies to build a multicultural nation state. On the other hand, multicultural society susceptibly triggers conflict and dissension. As suggested by Nasikum (2007:33), Indonesian society plurality can be seen at least from its two peculiar characteristics. Firstly, it is horizontally characterized with the reality of social units based on different ethnics, religions, customs, and localities. Secondly, it is vertically characterized with vertical sharp differences between upper and lower layers. Plurality and heterogeneity is bond to nation unity and integrity principle with slogan under the slogan of "Bhinneka Tunggal Ika or Unity in Diversity" meaning that despite diversity, Indonesia keeps integrated in unity.

Multiethnic and multicultural peculiarity in Indonesia is faced with a distinctive dilemma. On the one hand, Indonesia becomes a big nation as a multicultural nation-state, but on other hand it becomes a threat. Multiculturalism is a cultural foundation related to the achievement of civility very essential to the realization of civilized democracy and democratic civilization (Azra, 2002).For that reasons, the multiculturalism-based Pancasila and Civic Educationlearning can be used to realize the society civilization thereby creating a national solidarity power. Article 4 clause (1) of Law No.2003 about National
Education System mentions that "Education is held democratically, justly and nondiscriminatively by upholding human rights, religious, cultural, and nation plurality values".

The article above implies that multiculturalism paradigm becomes one concern in Indonesian national education. In this context, it can be stated that the main objective of multicultural education is to inculcate sympathy, respect, appreciation, and empathy attitudes to different religion and cultural adherents. It is important to create social harmony in multicultural society. Septiani's study (2017) concludes that the indicators of harmonious society are: democratic, participative, tolerant, civilized, independent, and obedient to the law. When Indonesians have those indicators, they will be more advanced and democratic.

Multiculturalism development should be absolutely inculcated in living within plural community. Indonesia as a multicultural nation should develop multicultural insight in any order of life based on diversity values (Gina, 2015). Multicultural education can be used at both descriptive and normative levels, representing issues and education problems related to multicultural community. Furthermore, multicultural-paradigm education is very important as it leads the students to have tolerant and inclusive attitude and perspective on the reality of diverse communities (Mahfud, 2011).School is a very appropriate means to introduce multicultural education to every generation from early age. For that reason, special strategy and approach are required that is appropriate to the existing references and realized according to the condition of Indonesian community. It meansthat the integration of multicultural education into Pancasila and Civic Education learning unnecessarily changes the curriculum existing at school, but it can be done through daily learning approach in the class (Utami, 2017).

Operational, multicultural-based Pancasila and Civic Education learning is the learning program providing multiple learning environment consistent with the students' academic and social needs. The implementation of Pancasila and Civic Education learning can be ideally done in school. It is because school has provided a space likely reinforcing knowledge base and life experience of students to value difference and plurality. To support the purpose and objective of multicultural education above, Pancasila and Civic Education learning can utilize local wisdom and culture. Local wisdom values such as gotong royong (mutual cooperation), tolerance, and solidarity are very good to inculcate to the students through Pancasila and Civic Education learning by teacher in the class. It is in line with Anik Ghufron (2017) finding that the relevant learning to inculcate Yogyakarta cultural values is Yogyakarta or local culture. It is also confirmed by Ramdani \& 
Sapriya (2017) stating that local wisdom values contained in Amanat Galunggung traditional manuscript can be a means of realizing the objective of Pancasila and Civic Education learning in Junior High Schools. Finally, diversity-based Pancasila and Civic Education learning as social adhesive of multicultural society just like James A. Bank's (2014) concept explained as follows: (1) the integration of education in Pancasila and Civic Education curriculum involving diversity in education culture aiming largely to remove prejudice; (2) the construction of science realized by fining out and understanding the existing diversity comprehensively; (3) the reduction of prejudice born from interaction between diversities in education culture; (3) human equality pedagogy giving equal space and opportunity to all diverse elements; and School culture empowerment.

\section{CONCLUSION}

From the result of research, the following conclusions can be drawn. Firstly, the profile of Pancasila and Civic Education teachers in Junior High Schools in Surakarta have underlied by educational background (bachelor of education) linear to their field and have had long experience with teaching. Secondly, Pancasila and Civic Education teachers have good experience with scientific activity in both local and national levels; therefore, the Junior High School teachers' understanding on the essence and objective of Civic Education is fairly good in Surakarta. Thirdly, multicultural-based Pancasila and Civic Education learning can be used to realize civilization within community thereby creating a national solidarity power. Therefore, the development of powerful Pancasila and Civic Education learning should be revised, particularly in the term of (a) the integration of local cultural values, and (b) learning strategy and methods supporting the mastery of Pancasila and Civic Education competency.

\section{REFERENCES}

[1] Azra, A. (2002). Konflik Baru Antar Peradaban: Globalisasi, Radikalisme dan Pluralitas. Jakarta: PT. Raja Grafindo Persada.

[2] Azra, A. (2006). "Pancasila dan Identitas $\begin{array}{ll}\text { Nasional Indonesia: } & \text { Perspektif } \\ \text { Multikulturalisme". Dalam Restorasi Pancasila: }\end{array}$ Mendamaikan Politik Identitas dan Modernitas. Bogor: Brighten Press.

[3] Banks, James A. (2014). The Canon Debate, Knowladge Construction, and Multikultural Education. American Educational Research Association Vol.22, No.5, 4-14.

[4] Budimansyah, Dasim \& Suryadi, Karim. (2008). PPKn dan Masyarakat Multi-kultural, Prodi PPKn-Sekolah Pascasarjana-UPI Bandung: Bandung.
[5] Gall, Meredith D, Gall, Joyce P, \& Borg, Walter R. (2003). Educational Research, An Introduction (Seventh Ed). Boston: Allyn and Bacon.

[6] Ghufron, A., Budiningsih, C.A., Hidayati. (2017). "Pengembangan Pembelajaran Berbasis Nilai-nilai Budaya Yogyakarta di Sekolah Dasar". Cakrawala Pendidikan. Juni 2017. Februari 2015. Th XXXIV. No 2.

[7] Gina Lestari. (2015). "Bhinneka Tunggal Ika: $\begin{array}{ll}\text { Khasanah } & \text { Multikultural di Tengah Kehidupan } \\ \text { Sara". } & \text { Jurnal Pendidikan Pancasila dan }\end{array}$ Kewarganegaraan. Th. 28, Nomor 1, Pebruari 2015.

[8] Kemendiknas. (2010). Pembinaan Pendidikan Karakter di Sekolah Menengah Pertama. Jakarta: Kemendiknas.

[9] Mahfud, Choirul. (2011). Pendidikan Multikultural. Yogyakarta: Pustaka Pelajar

[10] Miles, M.B.\& Huberman, A.M. (1992).Qualitative Data Analysis. Beverly Hills: Sage Publication.

[11] Nasikun. (2007). Sistem Sosial Indonesia. Jakarta: PT. RajaGrafindo Persada.

[12] Ramdani, Y.A. \&Sapriya. 2017. "Integrasi Nilai Kearifan Lokal Berbasis Naskah Amanat Galunggung pada Pembelajaran Pendidikan Kewarganegaraan”. Jurnal Masyarakat, Kebudayaan, dan Politik. Volume 30 Nomor 4 Tahun 2017. Bandung: UPI.

[13] Sa'dijah, Cholis. 2009. Unjuk Kerja Mahasiswa Peserta "Teaching Junior SecondaryMathematics In English"dalam Membelajarkan MatematikaBerbahasa Inggris Berbantuan Teknologi Informasi danKomunikasi. Jurnal Pendidikan dan Pembelajaran, (Jurnal Nasional Terakreditasi). Vol 16, No 2, Oktober 2009.

[14] Samsuri.(2010). Objektivikasi Pancasila sebagai Modal Sosial Warga Negara Demokratis dalam Pendidikan Kewarganegaraan. ACTA CIVICUS, 2 (2). pp. 169-180. ISSN 1978-8428.

[15] Sapriya dan Winataputra. (2003). Pendidikan Kewarganegaraan: Model Pengembangan Materi dan Pembelajaran. Bandung: Laboratorium PPKn UPI.

[16] Septiani, An-nisa NSI. (2017). "Pendidikan Kewarganegaraan dalam Menguatkan civil society di Indonesia (Studi pada tingkat SMA)". Dalam Prosiding Seminar Nasional dan Call for Papers "Aktualisasi Pendidikan Pancasila dan Kewarganegaraan untuk Memperkuat SendiSendi Kehidupan Berbangsa". AP3KnI Jawa Tengah, 25 Nopember 2017.

[17] Tilaar, HAR. (2007).Mengindonesia Etnisitas dan Identitas Bangsa Indonesia. Jakarta: Rineka Cipta.

[18] Undang-Undang Republik Indonesia No. 20 Tahun 2003. Sistem Pendidikan Nasional. Bandung: Citra Umbara.

[19] Utami, Prihma Sinta. (2017). "Pengembangan Pemikiran James A. Bank Dalam Konteks Pembelajaran". Dalam JPK: Jurnal Pancasila dan Kewarganegaraan. Vol. 2,No. 2, Juli 2017 ISSN 2527-7057 (Online), ISSN 2545-2683 (Printed).

[20] Winataputra, U.S. (2001). "Jati Diri Pendidikan Kewarganegaraan sebagai Wahana Pendidikan Demokrasi”, (Disertasi) Bandung: UPI. 